\title{
SISTEM EKONOMI LAISSEZ FAIRE ADAM SMITH
}

Oleh : Nela Novyanti (90100118098)

\author{
Jurusan Ekonomi Islam
}

Fakultas Ekonomi dan Bisnis Islam

Laissez Faire muncul pertama kali di Prancis menjelang berakhirnya zaman merkantilis yang diawali tahun 1756. oleh kaum Fisiokat. Isitah "Physiocrats" berasal dari bahasa Yunani, dari kata "physia" berarti alam, dan "cratain" atau "cratos" berarti kekuasaan. Secara harfiah berarti "supremasi alam", yang artinya percaya bahwa sumber daya alam adalah sumber dari kekayaan. kaum yang memiliki pemikiran bahwa kegiatan ekonomi dan manusia itu sama dengan sumber daya alam yang diciptakan tuhan penuh dengan keselarasan dan keharmonisan. Alam jagad raya tercipta memiliki harta kekayaan yang melimpah ruah baik bersumber dari lautan. Tuhan telah menciptakannya sebagai wasilah kehidupa manusia dalam memenuhi kebutuhan, naluri dan keinginannya. (Sirajuddin \& Tamsir, 2019). Begitupula ekonomi sehingga tidak perlu lagi adanya campur tangan pemerintah didalamnya. Beri manusia kebebasan, dan biarkan mereka melakukan yang terbaik bagi dirinya masing masing dengan demikian, setiap tindakan manusia dalam memenuhi kebutuhannya masing masing juga akan selaras dengan kemakmuran masyarakat banyak. (Faruq \& Mulyanto, 2017). Laissez Faire artinya "biarkan semua terjadi" Inilah yang kemudian menjadi cikal bakal Prinsip ekonomi yang diperkenalkan oleh Adam Smith (1729-1790) yang berpendapat bahwa pemerintah sebisa mungkin meminimalkan campurtangan atau intervensinya dalam kegiatan perekonomian. (Chabib, 2019).

Laissez Faire sendiri termasuk dalam kapitalis yang berarti biarkan ia berbuat dan biarkan ia berjalan. Maksudnya biarkan sajalah perekonomian berjalan dengan wajar tanpa adanya pemerintah nanti aka nada tangan tak terlihat 
(invusible hand) yang membawanya pada keseimbangan. Yang akan menciptkan upah harga yang stabil dan tingkat pengangguran yang rendah. Sehingga dianggap peran Negara perlu diminimalisir karena dianggap menggangu keseimbangan pasar. (Parakassi \& Kamiruddin, 2018)

Berbeda dengan merkantilisme yang yang menganggap bahwa ukuran kekayaan adalah emas dan perak dan perdagangan luar negeri, pada Laissez Faire ini justru menganggap bahwa kekayaan berasal dari sumber daya alam. (Faruq \& Mulyanto, 2017). Ini merupakan hasil kritikan adam Smith terhadap sistem ekonomi merkanilisme adam smith menganggap bahwa sistem ekonomi merkantilisme telah membatasi masyarakat untuk berkembang. Bagi smith negaraperlu memberikan kekuasan kepada pelaku pasar untuk menentukan kebijakan pasar mereka sendiri dengan mempertimbangakn keunggulan spesialsisasi dan produktifitas. Hal ini menurut nya akan mampu memotivasi masyarakat untuk terjun ke dalam pasar dan bersaing secara sehat dengan para pesaingnya. (Nasution, 2014). 


\section{DAFTAR PUSTAKA}

Chabib, M. (2019). Pengaruh Politik Negara Atas Mekanisme Pasar (Studi Analisis Ekonomi Politik Menurut John Rawls). Indonesian Interdisciplinary Journal of Sharia Economics (IIJSE) , 1, 17.

Faruq, U. A., \& Mulyanto, E. (2017). Sejarah Teori-Teori Ekonomi. Banten: UNPAM PRESS.

Nasution, A. P. (2014). Kaum Saudagar dalam Lingkaran Kekuasaan Negara. Jurnal Bening , 1, 3 .

Parakassi, H. I., \& Kamiruddin. (2018). Analisis Harga dan Mekanisme Pasar dalam Perspektif Islam. Jurnal Laa Maiysir , 5, 108.

Sirajuddin, \& Tamsir. (2019). Rekonstruksi Konseptual Kepemilikan Harta Perspektif Ekonomi Islam (Studi Kritis Kepemilikan Harta Sistem Ekonomi Kapitalisme). Jurnal Laa Maisyir , 6, 212. 